\title{
OPEN Author Correction: Early Pastoral Economies and Herding Transitions in Eastern Eurasia
}

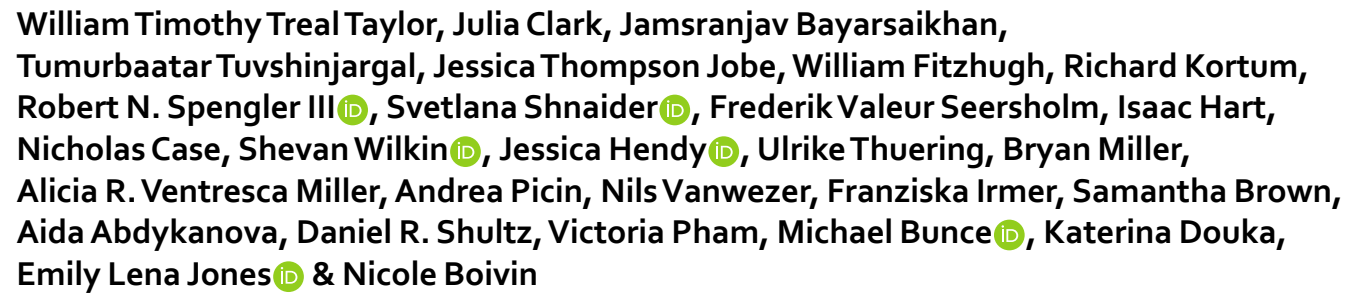

William Timothy Treal Taylor, Julia Clark, Jamsranjav Bayarsaikhan, Tumurbaatar Tuvshinjargal, Jessica Thompson Jobe, William Fitzhugh, Richard Kortum, Robert N. Spengler III (D), Svetlana Shnaider (D), Frederik Valeur Seersholm, Isaac Hart,

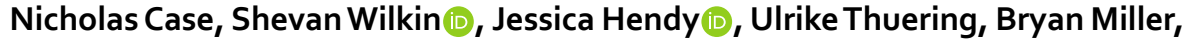
Alicia R. Ventresca Miller, Andrea Picin, Nils Vanwezer, Franziska Irmer, Samantha Brown, Aida Abdykanova, Daniel R. Shultz, Victoria Pham, Michael Bunce ${ }^{D}$, Katerina Douka, Emily Lena Jones (1) \& Nicole Boivin

Correction to: Scientific Reports https://doi.org/10.1038/s41598-020-57735-y, published online 22 January 2020

This Article contains a typographical error in the Introduction section under subheading 'Understanding Early Horse Domestication and Transport' where,

"Historical records refer to horse-mounted warriors in western Asia by the 8th century BCE, while archaeological finds from localities like Arzhan 2 in southern Tuva show specialized horse equipment (bronze snaffle bits) and equine vertebral pathologies linked with mounted riding in Central Asia by the late 9th century BCE ${ }^{31}$."

should read:

"Historical records refer to horse-mounted warriors in western Asia by the 8th century BCE, while archaeological finds from localities like Arzhan in southern Tuva show specialized horse equipment (bronze snaffle bits) and equine vertebral pathologies linked with mounted riding in Central Asia by the late 9th century BCE ${ }^{31}$."

(1) Open Access This article is licensed under a Creative Commons Attribution 4.0 International License, which permits use, sharing, adaptation, distribution and reproduction in any medium or format, as long as you give appropriate credit to the original author(s) and the source, provide a link to the Creative Commons license, and indicate if changes were made. The images or other third party material in this article are included in the article's Creative Commons license, unless indicated otherwise in a credit line to the material. If material is not included in the article's Creative Commons license and your intended use is not permitted by statutory regulation or exceeds the permitted use, you will need to obtain permission directly from the copyright holder. To view a copy of this license, visit http://creativecommons.org/licenses/by/4.0/.

(C) The Author(s) 2020 